\title{
PERAN NEGARA DALAM MENANGANI ANCAMAN KEAMANAN NON TRADISIONAL DI PERBATASAN: STUDI PELANGGARAN KEIMIGRASIAN DI KOTA BATAM
}

\author{
THE ROLE OF THE STATE IN ADDRESSING NON TRADITIONAL SECURITY THREATS AT THE \\ BORDER: STUDY OF IMMIGRATION VIOLATIONS IN BATAM CITY \\ Josua William Tambun ${ }^{1}$ Dhani Akbar ${ }^{2}$, Mohammad Riza Widyarsa ${ }^{3}$ \\ 1,2,3 Ilmu Hubungan Internasional, Universitas Maritim Raja Ali Haji \\ E-mail : Josuawilliamtambun9@gmail.com¹ akbardhani@umrah.ac.id 2 tedungok@gmail.com³
}

\begin{abstract}
ABSTRAK
Batam sebagai salah satu wilayah di Indonesia yang berbatasan langsung dengan dengan negara luar. Batam bukan hanya sebagai wilayah yang berbatasan langsung dengan Singapura dan Malaysia, namun Batam sendiri juga adalah daerah yang menetapkan sistem Kawasan Bebas (Free Trade Zone). Kawasan bebas itu merupakan sebuah sistem kebijakan otorita suatu daerah untuk mempermudah jalur perdagangan di kawasan perdagangan dan pelabuhan yang berada di Indonesia yang didalamnya berisi terjadinya proses penggudangan barang, kegiatan manufaktur serta kegiatan reekspor tanpa hambatan oleh otoritas kepabeanan/perpajakan. TOCs adalah kejahatan lintas Negara yang dilakukan secara terstruktur. Pada penelitian ini bersifat kualitatif. Penelitain kualitatif sendiri merupakan penelitian yang memberikan penekanan pada pendalaman pemahaman sebuah permasalahan. Dengan diciptakannya produk Mikroregionalisme dan Mikroregionalisasi, yang mana suatu produk negara yang dibarengi dengan aktor non negara pasti ada faktor-faktor yang mendukung untuk terjadinya ketimpangan.
\end{abstract}

Kata Kunci : Keamanan Non-Tradisional, Perbatasan, Sekuritisasi

\section{ABSTRACT}

Batam as one of the regions in Indonesia which is directly adjacent to foreign countries. Batam is not only an area directly adjacent to Singapore and Malaysia, but Batam itself is also an area that establishes a Free Trade Zone system. The free area is a policy system for a regional authority to facilitate trade routes in trade areas and ports in Indonesia which contains the process of warehousing goods, manufacturing activities and re-exporting activities without obstacles by the customs/taxation authority. TOCs are transnational crimes committed in a structured manner. This research is qualitative. Qualitative research is research that emphasizes deepening understanding of a problem. With the creation of products of Microregionalism and Microregionalization, which is a product of the state coupled with nonstate actors, there must be factors that support the occurrence of inequality.

Keywords : Non-Traditional Security, Border, Securitization 


\section{PENDAHULUAN}

Undang-Undang Republik Indonesia Nomor 6 Tahun 2011 tentang Keimigraian menggantikan Undang-undang Republik Indonesia Nomor 9 Tahun 1992 tentang Keimigrasian hadir sebagai produk kebijakan dalam menangani dan mencegah dampak negatif dari peningkatan arus orang asing ke wilayah Republik Indonesia lebih meningkatkan penerimaan Indonesia, meningkatnya investasi yang dilakukan, serta meningkatnya aktivitas perdagangan yang akan meningkatkan penerimaan devisa. Namun peningkatan arus lalu-lintas orang, barang, jasa, modal, dan informasi juga dapat mengandung pengaruh negatif, seperti dominasi perekonomian nasional oleh perusahaan transnasional yang bergabung dengan perusahaan Indonesia (melalui Penanaman Modal Asing dan/atau penanaman modal dalam negeri, pembelian saham atau kontrak lisensi). Selain itu, munculnya Transnational Organized Crimes (TOC), mulai dari perdagangan orang, pencucian uang, narkotika, dan obat terlarang, imigran gelap, sampai ke perbuatan terorisme internasional juga patut diwaspadai.

Batam sebagai salah satu wilayah di Indonesia yang berbatasan langsung dengan dengan negara luar. Batam bukan hanya sebagai wilayah yang berbatasan langsung dengan Singapura dan Malaysia, namun Batam sendiri juga adalah daerah yang menetapkan sistem Kawasan Bebas (Free Trade Zone). Kawasan bebas itu merupakan sebuah sistem kebijakan otorita suatu daerah untuk mempermudah jalur perdagangan di kawasan perdagangan dan pelabuhan yang berada di Indonesia yang didalamnya berisi terjadinya proses penggudangan barang, kegiatan manufaktur serta kegiatan reekspor tanpa hambatan oleh otoritas kepabeanan/perpajakan. Batam dikenal memiliki banyak pelanggar-pelanggar Asing yang melanggar keimigrasiannya. Dengan berdalih menggunakan Bebas Visa Kunjungan akan tetapi tidak hanya melakukan kunjungan biasa namun bekerja. Berdasarkan pada ketentuan undang-undang keimigrasian yang berlaku, setiap orang asing yang berada di Indonesia itu di batasi ruang lingkup geraknya, serta dapat juga di deportasi atau diserahkan ke negara lain, terutama bila melakukan tindak pidana di Indonesia.

Di bidang perekonomian, setiap warga negara asing yang bekerja atau memiliki usaha di Indonesia harus memiliki izin kerja yang di keluarkan oleh Kementrian ketenagakerjaan Indonesia dan izin tinggal yang di bagi 2 kategori yaitu Izin Tinggal terbatas dan Izin Tinggal Tetap yang dikeluarkan Kementrian Hukum dan HAM oleh kantor Imigrasi. Dalam bidang 
agraria atau pertanahan, warga negara asing yang bekerja ataupun berusaha di Indonesia tidak dapat memiliki hak kepemilikan lahan di Indonesia dan yang boleh adalah orang atapun perusahaan yang menjamin orang asing tersebut.

Dalam bidang politik, warga negara asing tidak diperkenankan turut campur dalam politik dalam negeri Indonesia. Hal ini akan mempengaruhi ke pola kehidupan serta tatanan sosial budaya yang dapat berpengaruh pada aspek pemeliharaan keamanan dan ketahanan nasional secara makro. Untuk meminimalisirkan dampak negatif yang timbul akibat mobilitas manusia, Orang Asing yang keluar ataupun masuk dan tinggal di wilayah Indonesia, keimigrasian harus mempunyai peranan yang semakin besar. Penetapan politik hukum kemigrasian yang bersifat selektif membuat institusi imigrasi Indonesia memiliki landasan operasional dalam menolak atau mengizinkan orang asing, baik dari segi masuknya, keberadaannya, maupun kegiatannya di Indonesia.

Dengan masih banyaknya pelanggaran yang di lakukan oleh imigran asing, kurang nya kesadaran dari pekerja asing tentang legalitas, masih banyaknya titik yang kurang dalam pengawasan, masih adanya oknum-oknum yang tidak bertanggung jawab ikut serta dalam pelanggaran yang dilakukan oleh orang asing yang berada di Indonesia. TOCs adalah kejahatan lintas Negara yang dilakukan secara terstruktur. Melihat dari banyak nya kasus yang menyalahgunakan perizinan tinggal yang di berikan oleh Imigrasi, maka dari itu pastinya ada indikasi oknum yang tidak bertanggung jawab yang menyalahgunakan. Pada dasarnya perizinan tinggal itu sendiri dibuat agar orang asing yang berada di Indonesa lebih terkontrol. Maka jika orang asing yang menyalahgunakan perizinin tinggal, sudah pasti tidak dapat terkontrol oleh pihak berwenang yang mana disini adalah tugas dari Keimigrasian itu sendiri. Dilihat dari bayaknya pelanggaran keimigrasian yang terjadi sudah pasti didalam tersebut sudah pasti ada indikasi melakukan tindak kejahatan yang dapat dikategorikan sebagai kejahatan lintas negara.

Dengan demikian, peran penting aspek keimigrasian dalam tatanan kehidupan kenegaraan akan dapat terlihat dalam pengaturan keluar ataupun masuknya orang dari dan ke dalam wilayah Indonesia, dan pemberian izin tinggal serta pengawasan terhadap orang asing selama berada di wilayah Indonesia, karena masih banyak imigran asing yang melakukan pelanggaran di Indonesia. Berikut beberapa dari identifikasi pelanggaran imigran asing: 
a) Belum maksimal nya pengawasan terhadap imigran asing yang berada di Indonesia, khususnya di kota Batam.

b) Rendahnya kesadaran dari beberapa Pekerja asing akan perizinan tinggal yang legal dari pemerintah

c) Minimnya sosialisasi terkait apa saja yang di perlukan untuk menunjang perizinan yang legal di Indonesia.

d) Masih banyaknya tempat di beberapa titik yang masih kurang jangkauan pengawasannya.

e) Adanya oknum yang bermain dengan orang asing yang tidak memiliki legalitas yang jelas saat berada di Indonesia.

\subsection{Rumusan Masalah}

Bagaimana peran Negara dalam menangani ancaman keamanan non tradisional tentang keimigrasian di kota Batam dalam konsep sekuritisasi?

\section{TINJAUAN LITERATUR}

\subsection{Sekuritisasi}

Dalam hubungan internasional, negara tidak hanya ditentukan oleh kekuatan militer atau ekonominya, akan tetapi juga ditentukan oleh nilai-nilai dan citra dari negara itu sendiri. Hal ini juga berkaitan dengan munculnya fenomena di mana cara Negara menyikapi kejahatan lintas negara merupakan faktor yang dapat mempengaruhi kebijakan sebuah negara. Berangkat dari pemikiran tersebut, penelitian ini didukung landasan Teori Sekuritisasi yang perspektif dasarnya adalah Realis. Ada banyak pengertian terkait dengan sekuritisasi seperti menurut Barry Buzan, Oleh Waever dan Jaap de Wilde yang dikenal sebagai kelompok Copenhagen School, sekuritisasi adalah "... the move that takes ... beyond the established rules of the game and frames the issue as either a special kind of politics or as above politics (Hartono, 2007). Jadi, sekuritisasi dapat disederhanakan sebagai suatu proses di mana suatu isu yang di pahami sebagai suatu masalah keamanan. Pada hakekatnya juga sekuritisasi adalah cara pandang dalam memahami atau memperlakukan isu yang berkembang sebagai suatu bahaya yang luar biasa 
disertai ancaman tingkat tinggi di luar batas kewajaran. Dengan teori sekuritasi maka peneliti mengambil paradigma Realisme.

Konsep pemikiran Realisme itu pada dasarnya manusia bersifat egosentrik dan konfliktual kecuali bila terdapat kondisi dimana manusia dapat hidup berdampingan. Dalam hal kepentingan pribadi, manusia lebih cenderung mengandalkan diri sendiri dan termotivasi mencari kekuatan yang lebih besar. maka dari itu, peneliti mengambil pradigma Realis karena peneliti memakai teori Sekuritisasi yang pada dasarnya sekurititasi tersebut lebih ke paradigma realis.

Teori sekuritisasi digagas untuk merespon keprihatinan terhadap keamanan tradisional yang memahami keamanan sebagai "security is what actors make of it" (Hartono, 2007). Sekuritisasi tersebut menurut para penggagas pendekatan teori sekuritisasi dapat diidentikkan melalui rekayasa politik, khususnya mengkaitkannya dengan kondisi krisis atau darurat melalui aksi-aksi yang dalam kondisi normal tidak dapat diterima. Dalam kondisi untuk mendeklarasikan pentingnya diambil suatu kebijakan keamanan.

\subsection{Mikroregionalisasi dan Mikroregionalisme}

Ada beberapa pendapat mengenai mikroregionalisasi dan mikroregionalisme. Menurut salah satu ahli Fredrik soderbaum "the formation of micro-regions which are more cross-border in nature rather than being contained within the boundaries of a particular nation-state. Notably, micro-regions exist between the "national" and the "local" level, and are distinguishable from larger macro-regions." (Manshur, 2019) sehingga posisi mikroregionalisasi itu sendiri berada diantara tingkat nasional dan lokal. Selain dengan dirancang secara alami yang lebih mengutamakan akivitas antar negara (cross-border) daripada aktivitas yang ada di negeri. Adapula menurut Breslin \& Hook "mikroregionalisme merupakan integrasi yang berlangsung dibawah tingkat nasional akan tetapi dapat melampaui batas negara dengan didorong oleh aktor negara, sedangkan mikroregionalisasi merupakan faktor yang menggambarkan proses integrasi dimana proses ini digerakkan oleh kekuatan pasar (aktor non negara) baik oleh perusahaan, para pengusaha lokal maupun asing, asosiasi industri, kelompok masyarakat, hingga individu.

Globalisasi dapat berdampak positif ataupun negatif. Interaksi antar aktor dapat terjadi semakin meluas karena adanya kasus yang diciptakan dari sebuah globalisasi. Salah satu akibat 
adanya globalisasi yaitu terbentuknya sebuah kerjasama internasional akibat hasil dari perundingan antara dua negara atau lebih untuk menjalin hubungan tertentu yang memiliki kepentingan untuk negara tersebut. Kerjasama internasional terbentuk karena kehidupan internasional meliputi berbagai bidang seperti ideologi, politik, ekonomi, sosial budaya, lingkungan hidup, pertahanan dan keamanan.

\subsection{Keamanan Non-Tradisional}

Dalam konsep keamanan non-tradisional, negara dapat berada dalam keadaan terancam oleh aktor-aktor yang beragam (tidak hanya terbatas pada negara lainnya) dan pada permasalahan yang beragam pula (tidak hanya terbatas pada permasalahan militer). Sehingga dalam proses sekuritisasi ini, negara juga dapat menjadi referent objects. Dalam perspektif ini, konsep keamanan bersifat terbatas atau didefinisikan secara sempit, sebagaimana dikemukakan oleh (Falk \& Jessop, 2003), "Security studies may be defined as the study of the threat, use and control of military force". Maksudnya menurut Walt, Studi keamanan merupakan studi mengenai fenomena perang. Pendekatan walt ini juga mewakili dari konsep realisme yang juga dikenal sebagai Traditional Security. Pendekatan dalam konsep keamanan Non-Tradisional ini beranggapan bahwa entisitas politik ada dibawah negara (state actors), selain dari tekanan yang berasal dari Internasional, juga berasal dari lingkungan domestik itu sendiri. Dalam artian hal tersebut bahwa negara dapat menjadi sumber ancaman keamanan warga negara. Sifat dari ancaman keamanan itu sendiri adalah multidimensional dan kompleks, karena ancaman kemanan ini tidak saja berasal dari militer akan tetapi bisa jadi berasal dari faktor lainnya seperti terjadinya perompakan, konflik etnik, masalah lingkungan hidup, kejahatan Internasional, dan sebagainya.

Landasan berfikir pendekatan Non-Tradisional diantaranya sebagai berikut:

1. Keamanan komprehensif yang menekankan pada aspek ancaman apa yang dihadapi oleh negara. Kandungan politik dari keamanan ini adalah upaya untuk menciptakan kestabilan yang mencakup semua aspek keamanan.

2. Bentuk ancaman yang dihadapi negara bisa saja berasal dari dalam negeri seperti tekanan individu, tekanan dari Lembaga Swadaya Masyarakat (LSM), dan kelompok masyarakat. Selain ancaman bisa berasal dari luar negeri, yaitu 
ancaman yang datang dari transaksi dan isu-isu yang melewati batas-batas nasional suatu negara seperti kejahatan internasional.

3. Faktor untuk menjelaskan perkembangan ini adalah proses globalisasi dan perkembangan teknologi informasi, demokratis dan hak azasi manusia, masalah lingkungan hidup, ekonomi, sosial, dan budaya.

Ancaman keamanan itu sendiri sebanarnya tidak hanya disebabkan oleh efek samping dari interelasi, interpendensi, interpenetrasi, interkoneksi, lintas tritori akan tetapi juga merupakan buah dari kreativitas dengan kesempatan yang tersedia dan teknologi yang mendukung yaitu kemunculan kejahatan model baru transnational crime. Saat ini menghadapi Transnational Crime merupakan ancaman terberat dalam keamanan non-tradisional. Bukan hanya menanggulanginya, mendeteksi keberadaannya pun sekarang agak sulit. Saat ini dihadapkan pada dilema, teritori yang mengikat padanya. Untuk mengakses jaringan transnational crime juga harus memiliki teritori yang tidak ingin dan memang harus ditaati tidak untuk dilanggar. Setiap negara pastinya mengamankan daerah teritori domestiknya daripada menyelengarakan keamanan global atau bahkan regional. Jikalaupun negara berhasil membangun komitmen dengan negara lain untuk memerangi transnational crime negara selalu memiliki kecenderungan mengedepankan national interest daripada global interest dalam pembuatan kebijakan.

\section{METODOLOGI PENELITIAN}

Pada penelitian ini bersifat kualitatif. Penelitain kualitatif sendiri merupakan penelitian yang memberikan penekanan pada pendalaman pemahaman sebuah permasalahan. Lexy Muloeng mendefinisikan penelitian yang menggunakan metode kualitatif ini mempunyai maksud untuk memahami fenomena tentang apa yang di alami oleh subyek penelitian, seperti prilaku, tindakan, motivasi yang di pahami secara menyeluruh menggunakan deskripsi dalam bentuk bahasa dan kata-kata. Metode kualitatif digunakan untuk menjawab pertanyaan tentang "apa (what)", "bagaimana (how)", atau "mengapa (why)" atas suatu fenomena, sedangkan metode kuantitatif menjawab pertanyaan "berapa banyak (how many, how much)". 
Untuk membatasi daerah penelitian agar pelaksanaan penelitian berjalan dengan efektif, maka penetapan lokasi penelitian merupakan hal yang cukup penting bagi peneliti. Oleh karena itu, berdasarkan judul yang diangkat maka lokasi penelitian berada di Kantor Pemerintahan kota Batam. Dengan ruang lingkup yaitu Kantor Imigrasi Kelas I Khusus TPI Batam, Polisi Daerah Kepulauan Riau (POLDA KEPRI) yang semua sama -sama berlokasi di kota Batam.

Tabel 1. Informan

\begin{tabular}{|c|c|c|}
\hline No & Informan & Jumlah \\
\hline 1 & $\begin{array}{c}\text { Kepala Bidang Intelejen } \\
\text { dan Penindakan Imigrasi } \\
\text { kelas I Batam }\end{array}$ & 1 \\
\hline 2 & $\begin{array}{c}\text { Kepala seksi Intelejen } \\
\text { Imigrasi kelas I Batam }\end{array}$ & 1 \\
\hline 3 & Intelkam POLDA KEPRI \\
\hline 4 & $\begin{array}{c}\text { Anggota Intelejen dan } \\
\text { Penindakan Kantor } \\
\text { Imigrasi kelas I Batam. }\end{array}$ \\
\hline
\end{tabular}

Sumber: Data Olahan, 2020

\section{HASIL DAN PEMBAHASAN}

Seiring dengan pertumbuhan pulau Batam sebagai kawasan industri, pariwisata dan perdagangan, Kantor Imigrasi Batam telah berkembang menjadi kantor dengan aktifitas kerja yang cukup tinggi setiap harinya. Padahal pada awalnya tahun 1971 Kantor Imigrasi Batam masih merupakan sebuah Pos Pendaratan di Pelabuhan Batu Ampar, yang berada dalam ruang lingkup koordinasi Kantor Direktorat Jenderal Imigrasi Belakang Padang. Kemudian dalam perkembangannya dibentuk Kantor Direktorat Jenderal Imigrasi Sekupang berdasarkan Surat Keputusan Menteri Kehakiman No. J.S.4/4/21 Tahun 1979 tanggal 12 Mei 1979. Kantor Direktorat Jenderal Imigrasi Sekupang tersebut diresmikan pada tanggal 7 April 1980 yang selanjutnya akan dikembangkan sesuai dengan kemajuan pembangunan kota Batam sebagai suatu daerah yang dirancang khusus sebagai wilayah relokasi industri sekaligus juga merupakan pintu gerbang Indonesia di daerah segitiga Singapura-Johor-Riau (Sijori).

Berdasarkan Surat Keputusan Menteri Kehakiman RI Nomor: M.03-PR.07.04 Tahun 1991 tanggal 15 April 1991, wilayah kerja Kantor Imigrasi Sekupang meliputi Kota Batam dikurangi 
Kecamatan Belakang Padang. Karena gedung Kantor Imigrasi Sekupang yang terletak di Sekupang kondisi bangunannya sudah tidak memadai lagi, maka dilakukan perpindahan kantor ke gedung baru yang berada di Batam Centre yang kemudian diresmikan pada tanggal 30 April 1994. Kantor Imigrasi Sekupang membawahi lima Tempat Pemeriksaan Imigrasi (TPI) dengan wilayah kerja yang mencakup Pulau Batam, Pulau Rempang, Pulau Galang dan Pulau Galang Baru.

Karena semakin besarnya pelaksanaan pembangunan di pulau Batam dan sekitarnya, maka berdasarkan Surat Keputusan Menteri Kehakiman RI Nomor M.04-PR.07.04 Tahun 1995 tanggal 7 Agustus 1995, Kantor Imigrasi Sekupang penamaannya berubah menjadi Kantor Imigrasi Batam dengan wilayah kerja yang meliputi Kota Batam (dikurangi Kecamatan Belakang Padang) yang juga meliputi Pulau Rempang, Pulau Galang, Pulau Galang Baru. Kantor Imigrasi Batan merupakan Kantor Imigrasi dengan klasifikasi Kelas I yang wilayah kerjanya sama dan disesuaikan dengan wilayah kerja otorita Batam. Berikut data kasus Warga Negara Asing (WNA) yang dirilis oleh Bidang Intelejen dan Penindakan Keimigrasian Kantor Imigrasi Kelas I Khusus TPI Batam:

Tabel 2. Jumlah kasus Pelanggar Tindak Admisitratif Keimigrasian 2019

\begin{tabular}{|c|c|c|c|c|c|}
\hline \multirow[t]{2}{*}{ NO } & \multirow[t]{2}{*}{ Keterangan } & \multirow[t]{2}{*}{ Rincian } & \multicolumn{2}{|c|}{ Jenis Kelamin } & \multirow[t]{2}{*}{ Total } \\
\hline & & & $\mathbf{L}$ & $\mathbf{P}$ & \\
\hline \multirow[t]{6}{*}{1} & \multirow{6}{*}{$\begin{array}{c}\text { Jumlah sesuai Izin } \\
\text { Tinggal }\end{array}$} & $\begin{array}{c}\text { ITK (Izin Tinggal } \\
\text { Keimigrasian) B211 }\end{array}$ & 2 & 0 & 2 \\
\hline & & $\begin{array}{l}\text { ITK (Izin Tinggal } \\
\text { Keimigrasian) }\end{array}$ & 1 & 1 & 2 \\
\hline & & $\begin{array}{c}\text { BVK (Bebas Visa } \\
\text { Kunjungan) }\end{array}$ & 71 & 11 & 82 \\
\hline & & $\begin{array}{c}\text { ITAS (Izin Tinggal } \\
\text { Terbatas) }\end{array}$ & 5 & 0 & 5 \\
\hline & & VOA (Visa On Arrival) & 7 & 0 & 7 \\
\hline & & Tanpa Izin Tinggal & 15 & 0 & 15 \\
\hline \multirow[t]{5}{*}{2} & \multirow{5}{*}{ Kewarganegaraan } & Amerika Serikat & 2 & 1 & 3 \\
\hline & & Australia & 1 & 0 & 1 \\
\hline & & Bangladesh & 1 & 0 & 1 \\
\hline & & Brazil & 1 & 0 & 1 \\
\hline & & China & 27 & 3 & 30 \\
\hline
\end{tabular}




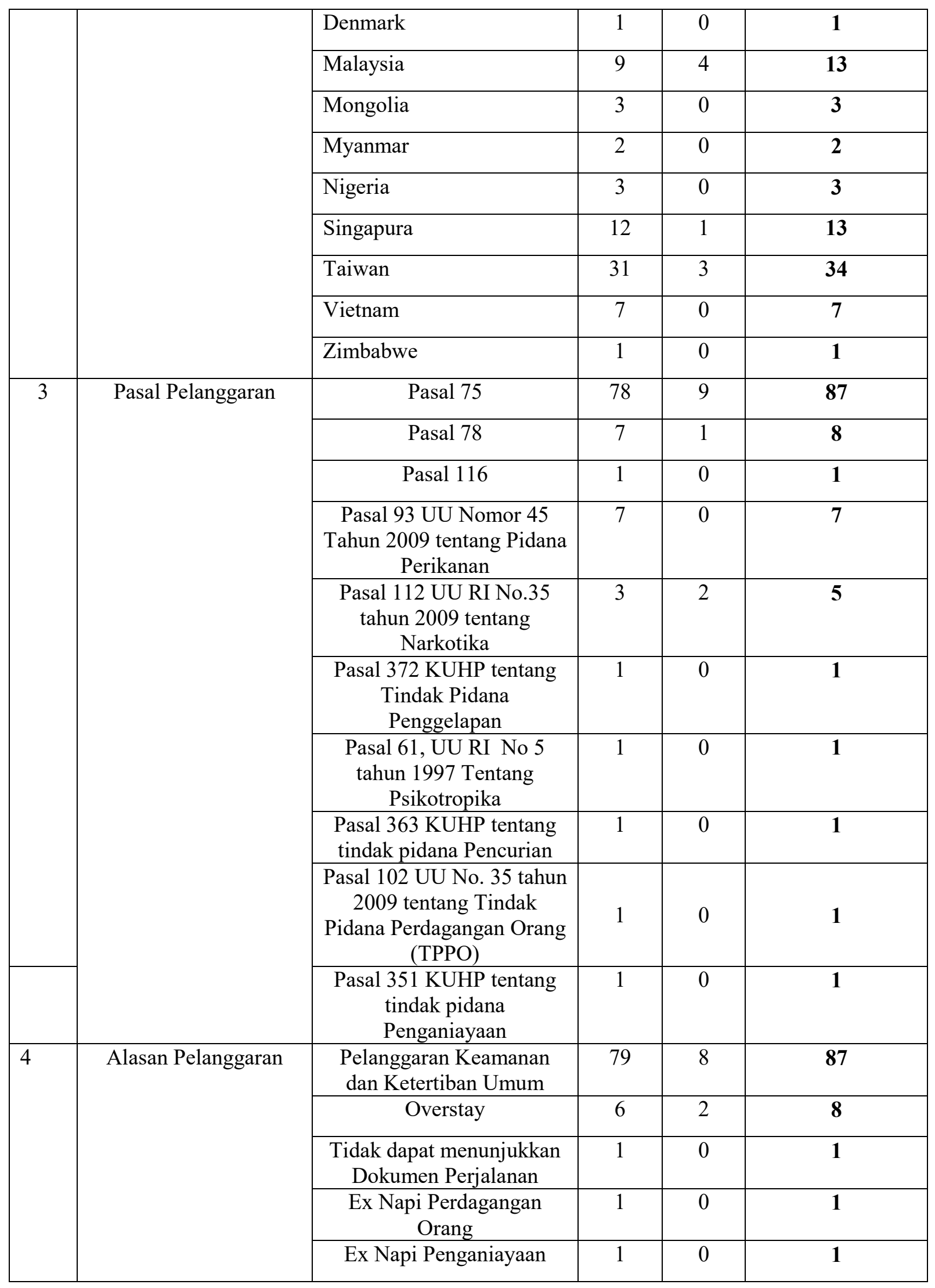




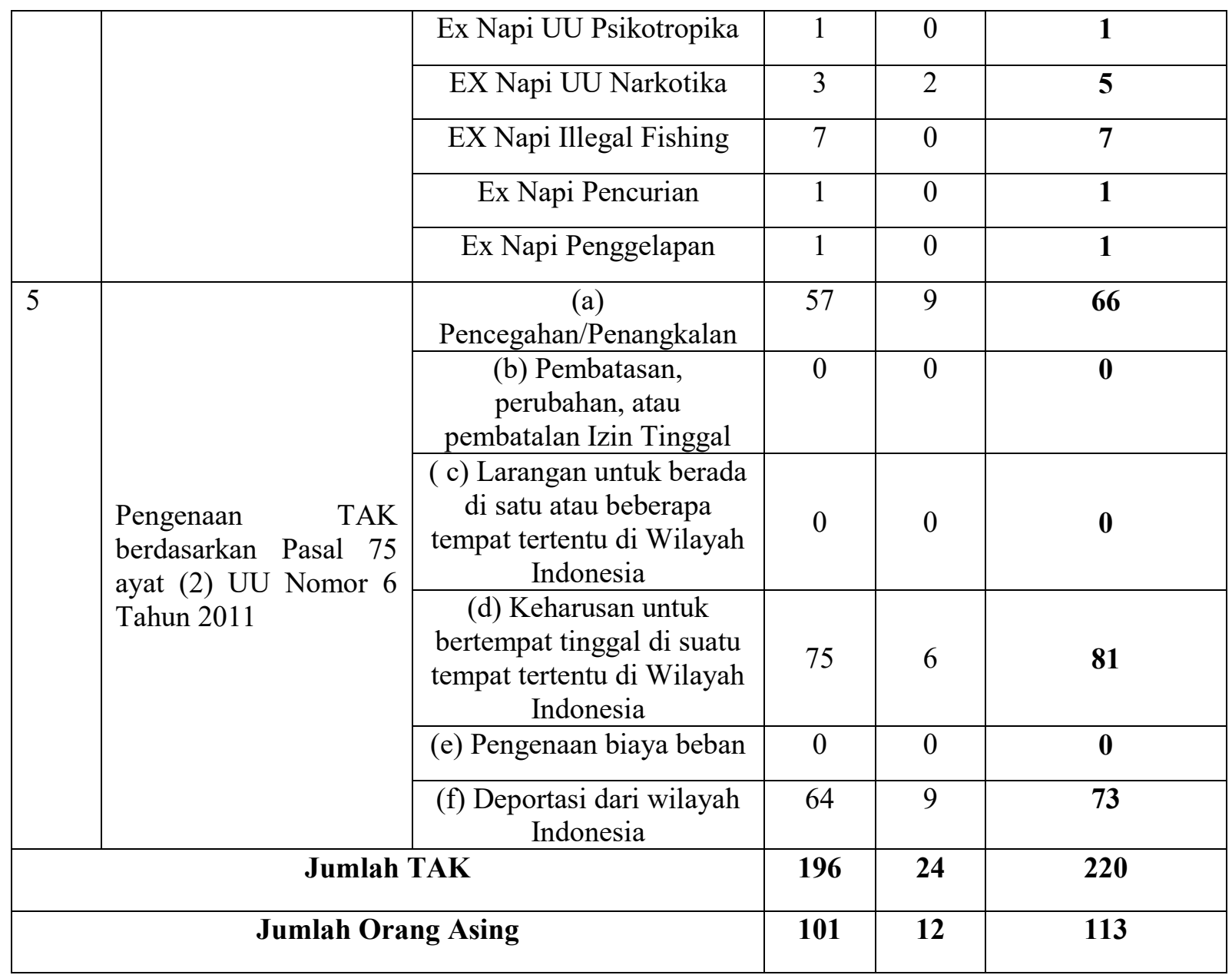

Sumber: Kantor Imigrasi Kelas I Khusus TPI Batam-Inteldakim, 2020

Berdasarkan data di atas dapat di lihat masih ada saja warga negara asing yang melanggar administratif keimigrasian dari Januari-Desember 2019. Untuk mencapai tujuan pengawasan yang lebih terhadap imigran asing, Imigrasi kelas I Khusus TPI kota Batam melakukan upaya sebagai berikut:

1) Melakukan pengawasan lebih ke tempat yang biasasnya rawan akan jalur masuk ilegal

2) Melakukan tindakan administratif keimigrasian terhadap imigran yang melakukan pelanggaran di Indonesia

3) Lebih memerhatikan sikap dan tingkah laku yang bersangkutan yang mengundang kecurigaan atau yang bersangkutan menderita gangguan jiwa, penyakit menular yang dapat membahayakan kesehatan umum 
Melihat informasi bahwa diduga yang bersangkutan akan menyelengarakan perbuatan yang bertentangan dengan moral, agama atau kebiasaan di Indonesia lebih ketat terhadap pemantauan orang asing yang bias terindikasi dapat melakukan pelanggaran di kota Batam.

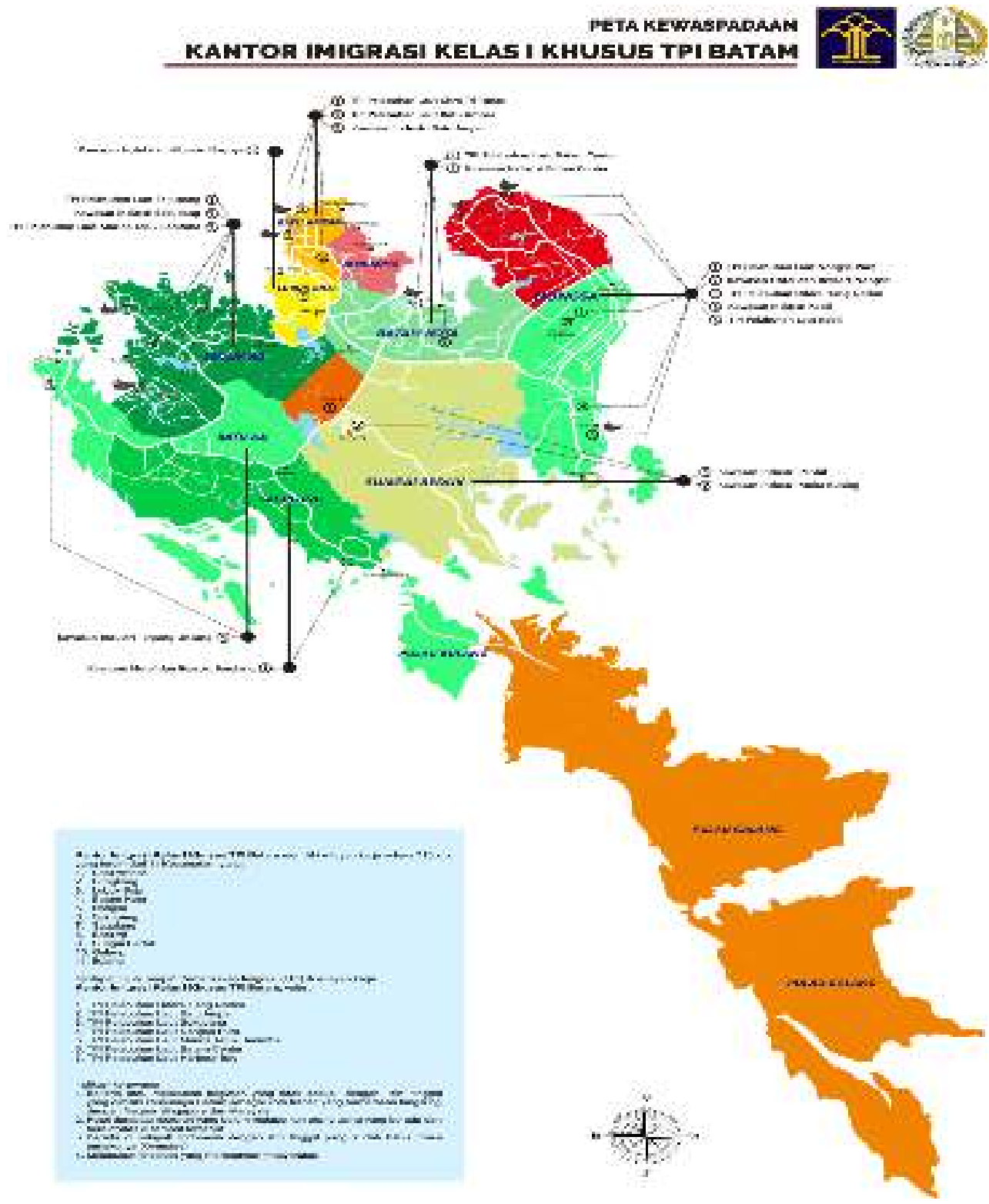

\section{Gambar 1. Peta Kewaspadaan Imigrasi} Sumber: Inteldakim 2019

TOCs sering juga dikaitkan dengan ancaman kompleks atau kejahatan terorganisasi, white-collar crime, dan korupsi yang muncul kerena doktrin "kejahatan sebagai bisnis" (Akbar \& Indrawan, 2018) Dengan diciptakannya produk Mikroregionalisme dan Mikroregionalisasi, yang mana suatu produk negara yang dibarengi dengan aktor non negara pasti ada faktor-faktor 
yang mendukung untuk terjadinya ketimpangan. Aktor non negara pasti memiliki kepentingankepentingan. Untuk mendukung kepentingannya tersebut tercapai, aktor non negara pasti melakukan berbagai cara untuk mencapainya. Aktor non negara disini dapat katakan secara umum adalah pihak asing. Karena mikroregionalisme itu dibentuk untuk lebih berhubungan kepada pihak asing. Dengan adanya berbagi kepentingan yang ada, jika tidak tercapai suatu kepentingan tersebut dapat menimbulkan indikasi terjadinya kejahatan. Jika kejahatan yang ditakutkan terjadi, pasti ada saja oknum-oknum yang ingin mengambil keuntungan untuk masuk didalam hal tersebut.

Dari TOCs melihat kejahatan lintas negara dari perspektif yang berbeda, tidak melihat dari human trafficking, drugs smuggling yang telah biasa di teliti sebelumnya. Disini peneliti melihat dari faktor pelanggar yang melanggar aturan dan oknum yang melakukan penyalahgunaan kekuasaan (Abuse of power).

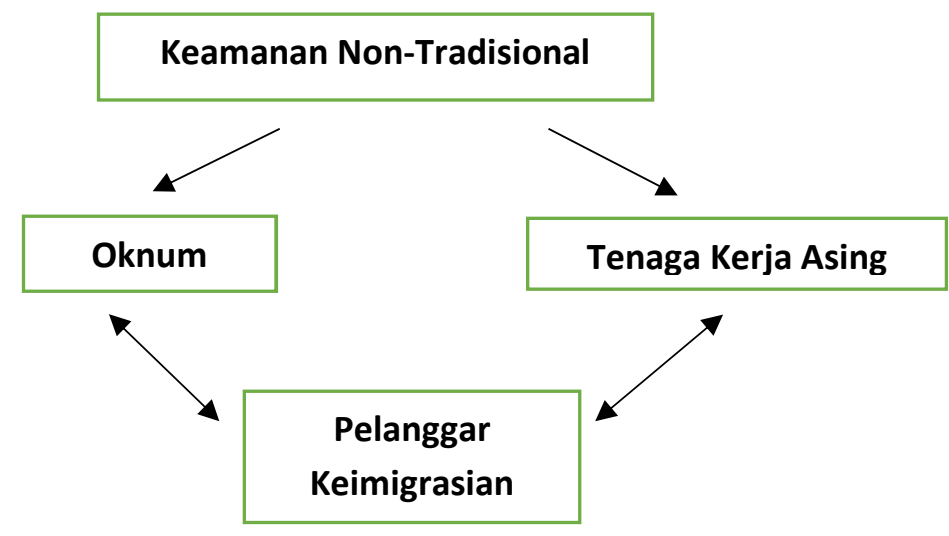

\section{Gambar 2. Skema Keamanan Non-Tradisional Sumber: Olahan Data Peneliti 2020}

\section{KESIMPULAN}

Pada penelitian ini peneliti dapat menyimpulkan dengan adanya ketidak sinkronan data yang disajikan dengan yang ada di lapangan. Dapat disimpulkan sudah ada oknum yang bermain dalam kasus ini. Mulai dari tenaga kerja asing yang bekerja di kota Batam sampai ke pada pihak yang mempunyai tupoksi dalam pengawasan orang asing yang berada di kota Batam, khususnya orang asing yang bekerja di kota Batam. Dalam penelitian ini peneliti ikut serta dalam 
melakukan beberapa pengawasan terhadap orang asing. Mulai dari pengawasan orang asing yang hanya melakukan kunjungan sampai ke orang asing yang tingal dan bekerja di kota Batam.

Dalam penelitian ini peneliti mendapat beberapa kendala dalam mendapatkan data dalam mendapatkan data yang lebih. Peneliti tidak mendapatkan respon dari instansi yang ingin didapatkan data untuk skripsi ini. Peneliti telah memberikan surat sebagai tanda legalitas penelitian ini, namun tidak ada balasan dari surat yang telah dimasukkan peneliti. Dalam hal ini, peneliti mendapatkan data untuk menunjang penelitian ini pada saat peneliti sedang magang di Kantor Imigrasi kelas I khusus TPI Batam. Selain pada saat magang, peneliti juga mendapatkan data dari orang yang peneliti kenal untuk mendapatkan data yang dapat mendukung data pada penelitian ini.

\section{DAFTAR PUSTAKA}

\section{Buku:}

Gatot Supramono, Hukum Orang Asing di Indonesia, Jakarta Timur : Sinar Grafika, 2012,

Laporan Tenaga Kerja Asing 2019, Intelejen dan Keamanan POLDA KEPRI

Lexy J. Muloeng, Metodologi Peneitian Kualitatif (Bandung: PT. Remaja Rosdakarya, 2000).

Miles dan Huberman, "Quantitative Data Analysis: An Expanded Sourcebook”, dalam Nanang Martono, “Metode Penelitian Sosial: Konsep-Konsep Kunci”, (Jakarta: PT RajaGrafindo Persada, 2015), Hlm. 11.

Undang Republik Indonesia Nomor 6 Tahun 2011 tentang Keimigraian menggantikan Undang-undang Republik Indonesia Nomor 9 Tahun 1992 tentang Keimigrasian.

Undang-Undang Keimigrasian Nomor 9 Tahun 1992 tentang Keimigrasian.

Undang-Undang Nomor 31 Tahun 1999, UU Nomor 20 Tahun 2001 


\section{Jurnal:}

Akbar, D., \& Indrawan, I. (2018). Tinjauan Hukum Dan Peran Pemerintah Dalam Tindak Pidana Perdagangan Orang (TPPO) di Kabupaten Karimun Dan Kota Batam. Jurnal Selat, 5(2), 134-147. https://doi.org/10.31629/selat.v5i2.467

Falk, R., \& Jessop, B. (2003). Theories of New Regionalism. Theories of New Regionalism, January 2014. https://doi.org/10.1057/9781403938794

Hartono, B. (2007). Copenhagen School: Sekuritisasi. 2007, 1-16.

Manshur, F. M. (2019). Kajian Teori Formalisme Dan Strukturalisme. SASDAYA: Gadjah Mada Journal of Humanities, 3(1), 79. https://doi.org/10.22146/sasdayajournal.43888

Wijaya, I. A., Wijayanti, O., \& Muslim, A. (2019). Analisis Pemberian Reward Dan Punishment Pada Sikap Disiplin Sd N 01 Sokaraja Tengah. Jurnal Educatio FKIP UNMA, 5(2), 84-91. https://doi.org/10.31949/educatio.v5i2.17 